\title{
The Ownership of Evil: 1968, 1989, and the Mainstreaming of the New Right
}

Branislav Jakovljević

Department of Theater and Performance Studies, Stanford University, 375 Santa Teresa Street, Stanford, CA 94305, US

https://orcid.org/0000-0003-2393-6648

bjakov@stanford.edu

\begin{abstract}
1968 was a watershed year not only for the new left but even more so for the rise of the New Right. It turns out that, if 1968 "prepared" 1989 as the next turning point in European and world history, it was probably more through the new right's forging of ideas that would eventually provide ideological justification for illiberal democracies in Central and Eastern Europe. Yugoslavia is an important site in this history not only because of its early exposure to the ideas of the new right through the work of the painter and publicist Dragoš Kalajic but also because in his seminal book The Philosophy of Parochialism (1969), Radomir Konstantinović anticipated the rise of the new right and offered a penetrating critique of its fundamental premises.
\end{abstract}

Keywords: art and politics / Yugoslavia / 1968-1989 / New Right / Evola, Julius / Kalajić, Dragoš / Konstantinović, Radomir: The Philosophy of Parochialism / metaphysical fascism / province / empire

\section{Hiding in plain sight: New right in SFRY}

On the occasion of the twentieth anniversary of "May," Serbian painter Dragoš Kalajić headlined his column in Belgrade biweekly Duga with a formula that spelled out his assessment of these events: "1968+20=0." As Europe and the world were nearing the largest watershed since WWII, the legacy of this world-wide series of protests, in Kalajić's judgment, amounted to nothing. The implication of making this statement in the spring of 1988, as the eastern bloc was beginning to crumble down, was that the historical defeat of real socialism had nothing to do with the near-triumph of the new left two decades earlier. In his signature style that combined strong opinions, sensationalism, and vagueness, spiced with autobiographical details and 
rumors, Kalajić dismissed student protesters as a bunch of armchair revolutionaries, only to suggest that the real nature of the unrest was a coup against Europe, specifically against de Gaullist idea of "Europe from the Atlantic to the Urals," funded by "supra-national capitalism made in USA" and orchestrated by "CIA and parts of the KGB" (Kalajić, "Maj 1968" 22; emphasis in the original). So much for a grand historical plot.

On a more personal level, the author of the column speaks of his memories of 1 March 1968 (printed, in a telling mistake, as 1986) when in the streets of Rome, Italy, he smelled teargas and heard chanting "Tutti uniti contro tutti i partiti! (All united against all parties!)." The narrator relates that this slogan ignited some hope in him until he realized that there was no unity among demonstrators, who were divided into two broad groups: "democrats," who were, according to Kalajić, consumers of "slops and cadavers of antiquated vulgar Marxism," and who relegated everyone else to the second group which they summarily labeled as "fascists" (21). He goes on to elaborate on this vague characterization of fascism, which clearly annoyed him, by another reminiscence, this time of his visit to a meeting of artists who were planning a disruption of the Venice Biennial, in which even a small expression of skepticism by "one De Dominicis" was dismissed as "fascist." What he does not mention was that the artists planned this intervention in order to call attention to the need to change Biennale statutes which had been established during Benito Mussolini's fascist regime (Barilli 13). Kalajić's choice of Dino De Dominicis, a notoriously controversial and reclusive Italian conceptual artist, as a protagonist of this episode can be seen as a shrewd move. So was his downplaying of the fascist 1968.

In fact, on 1 March 1968, young members of the left and right political groups protested together at Valle Giulia in Rome in a demonstration that some historians consider the starting point of the "Italian events of 1968" (Mammone 216). While this alliance was short-lived, it highlights the signal importance of 1968 for the formation of the "New Right," which has been during the 1970s overshadowed by the "New Left." The same year, on the other side of the Alps, Alain de Benoist established his extreme right think-tank GRECE (Groupement de recherche et d'études pour la civilization européenne); that same winter, several neo-fascist groups were dissolved, and many of their members joined the political party New Order (Ordre Nouveau). Following its dismal results in the 1971 elections, New Order reorganized and joined forces with other conservative and neo-fascist forces to form Front 
National. In October 1972, Jean-Marie Le Pen was elected as its leader. ${ }^{1}$ While the intellectual New Right kept itself at arm's length from political parties that drew on the legacy of the "old right," in the ensuing decades, they certainly helped political conservatives to refine their ideas and advance significantly from their positions in the early 1970s, when they seemed doomed to subsist on the fringes of the political spectrum in France.

Ideas of the New Right entered Yugoslavia quietly, mostly through the writings of that same Kalajić. In the early spring of 1968, he published his first book Wreckage (Kř̌evina), which concludes, as it were, with 1 March demonstrations at Valle Giulia (which he mislocates as Via Corso). For its very last words, he chose the slogan he quoted twenty years later, slightly shortened to "All united against parties." Wreckage is a slim volume published in the edition "Independent publications (Nezavisna izdanja)" that architect Slobodan Mašić started only a couple of years earlier. Part an artist book, part a poem, and part diary, Wreckage is a rant marked by a set of recurring ideas, such as that of Indo-European culture, the solitude of a rhinoceros and eagle, and disgust for the culture of modernism (psychoanalysis, surrealism, dada, James Joyce, and above all, Franz Kafka). His rejection of the avantgarde notwithstanding, the author insists on an experimental approach to writing, which includes visual and sound poetry, and ready-made techniques. His writing shifts freely from poetry to prose, is interrupted with a text that resembles a mathematical formula, breaks into a series of word-drawings, and finally disappears in an entire section made from pages cut out from magazines and daily newspapers. In their own right, these interventions speak volumes about the unreliability of assessing political attitudes of literary works by their "playfulness." Apparently, not only the writers on the left messed with formal conventions of literary texts.

\footnotetext{
${ }^{1}$ For more on French New Right and 1968, see Mammone.
} 


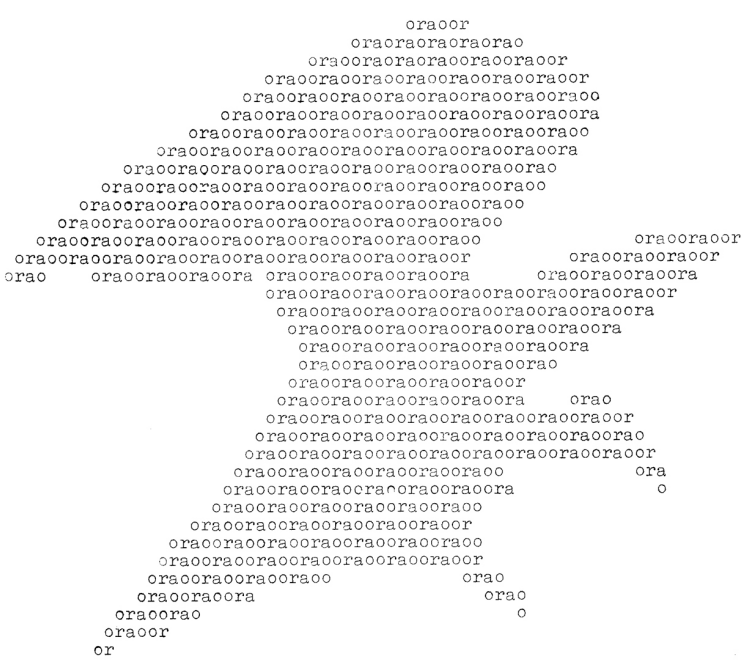

Figure 1: Dragoš Kalajić, Wreckage, visual poem "The Eagle"

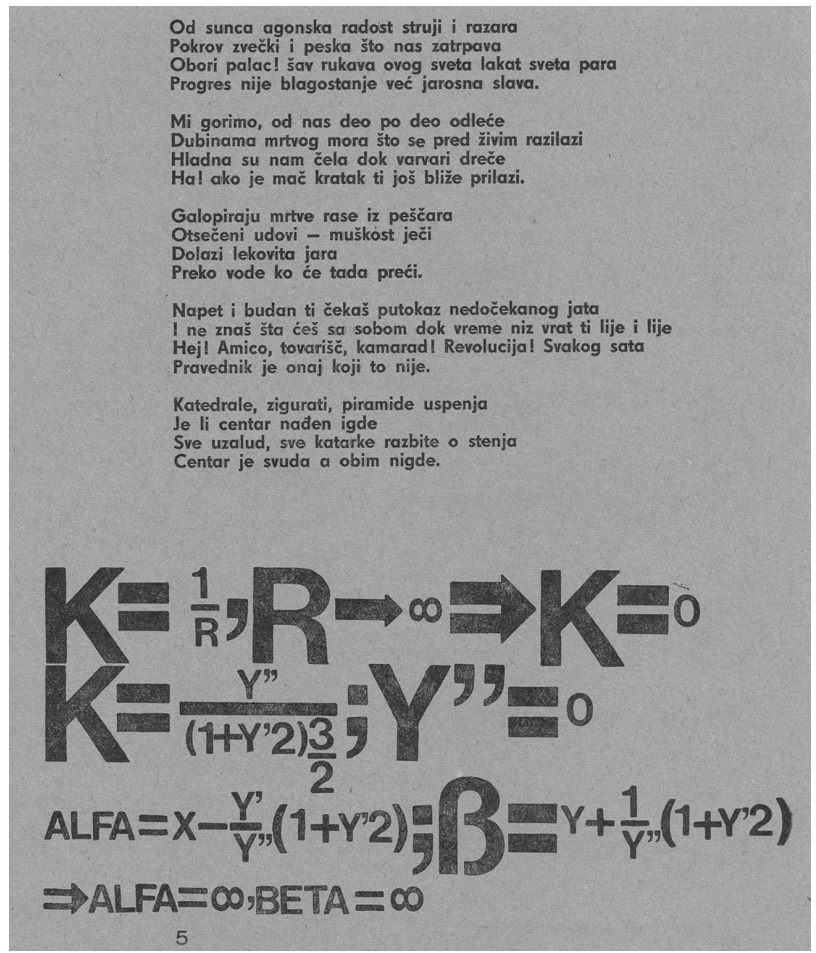

Figure 2: Dragoš Kalajić, Wreckage, poem-formula 
The formal dimension of Kalajićs prose, if not the ideas themselves, changed significantly in his second book, The Stronghold: A Rehabilitation of Integral Man's Structure (Uporište: rehabilitacija strukture integralnog coveka), published three years later by Nolit, one of the leading publishing houses in post-WWII Yugoslavia. The turning point for Kalajić might very well have been the republication, in 1969, of Julius Evola's The Revolt Against the Modern World, which originally came out in Mussolini's Italy in 1934. While Evola's name does not appear in an offhand list of otherwise uncredited sources that Kalajić included in the final pages of Wreckage, it figures prominently in The Stronghold. The young painter had ample opportunities to get acquainted with Evola's ideas during his student years in Rome, where he studied painting at Accademia di Belle Arti, graduating in 1966. Upon his return to Yugoslavia, Kalajić quickly developed a prominent and easily recognizable profile on Belgrade cultural scene. With his carefully crafted image of a man of taste clad in white suits and wearing bow ties, he held solo exhibitions, curated and participated in group shows, styled himself as a spokesperson of Mediala, one of the most prominent art groups in Yugoslavia established in the late 1950s, contributed in important modernist literary journal Delo, and built a highly visible profile as a columnist for weekly newsmagazine magazine $A s ̌$. In 1978 he published his third book, A Map of (Anti) Utopias (Mapa (Anti)utopija), in which he further elaborated on the ideas he first brought up in The Stronghold, all of which come from Evola, and more broadly, from the arsenal of the New Right: from the signs of the decline of the West in contemporary culture, to the ideas of the "integral man," "supreme center," and "Uranic culture." In the 1970s, Kalajić's politics went unnoticed most likely because Party ideologues, alarmed by a week-long student protest at Belgrade university in June of 1968, trained their attention on the "New Left," while not even registering the "New Right." ${ }^{2}$ No less significant was the care with which he concealed his ideology behind opaque language studded with commentaries which seemed in line with Party doctrines of that time, such as rejection of socialist realism in painting and the condemnation and ridicule of the 1968 student movement. During the 1980s, his reactionary politics became increasingly palatable to nationalists within the League of Communists and outside of it. By the end of that decade,

${ }^{2}$ Later in his career, he relished mentioning that his publisher pulled The Stronghold out from the circulation. Kalajić, however, was never subjected to censorship in the way in which some other writers and film-makers were in that same period. 
he started contributing to the weekend issue of highly influential daily Politika and became an editor of the book series Kristali in the publishing house Prosveta, thus getting an opportunity to promote some of his intellectual heroes, such as René Guénon, French traditionalist and an important source of Evola's doctrines.

During the fateful weeks in the fall of 1989, Kalajić was busy writing an introduction to the Serbian translation of Evola's 1958 Metaphysics of Sex. He used this opportunity to discuss the ideas of his intellectual mentor finally openly, and in doing so, to present his most fundamental political views. For example, he defends and justifies the Italian author's spurious distinctions between his "spiritual" theory of race as opposed to "vulgar" and "materialist" race theories, or between "fascist movement" and "fascist regime" (Kalajić, "Uvod" n. pag.). According to Evola, the former is epitomized in "Pagan imperialism" which privileges aristocracy and hierarchy, and the latter in a "totalitarianism of the demos" that comes from below. Kalajić concludes that "Evola saw in fascism a possibility of realizing of an ideal of the state which was held, under different forms and names, by a number of eminent representatives of aristocratic-sacral worldview, from Plato, through Friedrich II and Dante, to counter-revolutionaries such as [Joseph] de Maistre and [Juan] Donoso Cortés" (n. pag.). In 1989, these "metapolitical" doctrines seemed on full display in global politics: all Kalajićs readers needed to do was to look through their windows to convince themselves that Evola and his humble follower were right all along. Kalajić's columns in Duga, and even the visuals used in this magazine in which he exerted a considerable editorial influence, suggest that everything that 1989 stood for in Yugoslavia (the breakdown of socialism, institutional disorder, the rise of nationalism, etc.) presented him with an opportunity to return to his intellectual sources from two decades earlier. In the issue from November 11-24, 1989, Kalajić published a column entitled "Potemkin's Empire" (Potemkinova imperija) in which he explained that the Soviet Union was living the fate of all "pseudo-empires," which were, unlike "classical, authentic empires" founded on "plunder and exploitation" (Kalajić, "Potemkinova" 41). He concludes the column with a personal note about coming across his book The Standpoint (Uporište, 1971) at an antiquarian book fair, which prompted him to recall ("with a melancholy smile") his own prophetic words from the late 1960s. 


\section{Knights of endtimes}

All of this is not to say that at the time when Kalajić introduced the ideas of the New Right in Serbia and Yugoslavia, this culture did not have a response to this political thought that seemed so outlandish at that time and which became so outrageously widespread five decades later. That penetrating analysis of the deepest sources of fascist worldview did not come from the representatives of mainstream Marxism or their critics from Praxis group, but from an author that was concerned with literary criticism rather than with a critique of ideology, and in a volume that seemed at a great remove from the politics of the day. A case in point is Radomir Konstantinovićs book The Philosophy of Parochialism (Filosofija palanke), which first reached the audience in August of 1969 as broadcast on Radio Belgrade's Third Program, and came out in printed form the same fall. Formally, the subject of Konstantinović's book is Serbian lyric poetry from the first half of the $20^{\text {th }}$ century. That is only a starting point for a far-reaching work of philosophical anthropology. While Konstantinović's critics from the nationalist camp never forgave him that he concludes the book with a long section dedicated to "Serbian Nazism," initially, his main interest was not in the history of pro-Nazi political organizations in Serbia, but in what he called the "poetics of Nazism." At the very center of this foundational fascism is the idea of the province, or more specifically, of palanka.

What is palanka? A special case of "province," this word most commonly refers to a small town: not quite a village, and not a big city either. It came to Serbian from Hungarian palánk and French palanque, designating a timber stockade, suggested by its Latin root word planca, meaning board, plank, slab, or a piece of timber. Palanka is a settlement that is enclosed, fortified, and on guard from the outside world, which it perceives as foreign and hostile. Insularity is one of its main characteristics. If "province" is most commonly associated with $19^{\text {th }}$ century overseas colonialism, palanka belongs to the legacy of contiguous empires, from Roman Imperium to Austro-Hungarian and Russian empires of the modern era. ${ }^{3}$ A careful reading of Konstantinovićs book shows that palanka is the truth of the empire. ${ }^{4}$ Further, it shows how the outlandish constructions of Evola's or de Benoist's "metapolitics" can take a firm grip on actual political reality.

\footnotetext{
${ }^{3}$ For an example of a productive critique of imperialism from the perspective of former colonies, see Dipesh Chakrabarty's Provincializing Europe.

${ }^{4}$ In the remainder of this essay, I will use English words "province" and "parochialism" instead of Serbian palanka.
} 
Evola based his "metaphysical fascism" on a specific understanding of the past, which replaces historicism with mythology. Paul Furlong suggests that "he thought of myth (for example, the myth of the superior race) as a form of mobilization of society that the superior elements within it would move beyond, so as to be able to perceive the spiritual reality of which the myth is a crude and temporary expression" (Furlong 145). This mythical past is centered on the idea of the classical empire, infinitely superior to the vulgar imperialism of the capitalist era. This is precisely the key in which Kalajić interprets the events of November 1989. Speaking of the downfall of the Soviet "pseudo-empire," he insists that the classical empires were characterized by "splendid isolation" which guaranteed stability, exemplified in "pax romana" (in English and Latin, respectively, in the original). To illustrate this point, he refers to the Chinese wall and Roman limes, while conveniently forgetting the Berlin wall and isolationism that the Soviet Union inherited from tsarist Russia (Kalajić, "Potemkinova" 40). Evola and his epigones propose that, while vast but clearly defined in space, the idea of the "classical empire" reaches into the deepest recesses of history. Its sources are located far beyond the "classical" in a strict historiographic sense, to get lost in the mists of mythical time. Evola holds that "the transcendental principle of imperium" is best exemplified in Rome (Evola 40). It is the center of the empire and, as such, the epitome of order and stability (30). Sometimes referencing his intellectual source and more often plainly plagiarizing, Kalajić talks about the figure of the Holy Empire as a realm of ideality, and Rome as an ideal city. While the idea of an impermeable boundary (wall, limes) curtails the imperial logic of limitless expansion, it also reveals its most striking commonality with the province (palanka). Parochial spirit is distinguished by its "absolute fidelity to closedness" (Konstantinović, Philosophy 183). The provincial "is anti-historical, heeding a feeling of timeliness of his style and, confined to a closed world, the bidding to accept that insularity as a matter of his advantage and, again, of his own choice, rather than that of another's condemnation" (41). The province, as the epitome of insularity and closedness, is not the opposite of the "classical empire," but is, in fact, its defining element. Positioning themselves at the outer limits of the historical "metropole," metaphysical fascists fully inhabit the position of radical parochialism.

Evola and his followers are careful to note that they are not talking about modern colonial empires. Paradoxically, that brings Konstantinović's analysis to bear all that more on their kind of thinking. Palanka is a special case of the province: it is not a region, but a 
small town or a fortified settlement. As such, it is the product of contiguous empires, from Rome all the way to the Third Reich. This variety of the province captures with astonishing accuracy the position of the twentieth-century "philosophical" fascisms. These "philosophers" who style themselves as modern-day aristocrats of thought strikingly resemble provincials trapped between an idealized past of the "tribe" and a menacing, decadent "world." While claiming to strive towards a revival of noble past, this spirit thrives on present anxieties. For example, do we need to even mention "foreigners" and "immigrants" as the "danger" that has been energizing the New Right from its beginnings in the late 1960s until the present: "There is no doubt that for this spirit of a tribe in agony the fear of contact with a foreign culture is inevitable: everything foreign (here [non-Indo] "European"), is a temptation for the autochthony of this tribal spirit, the temptation of its alienation, while it seeks to remain generic (the spirit of genus)" (Konstantinović, Philosophy 251). And further: "It is a tribal thought, or the thought of a tribe in agony, the thought of the parochial spirit which, trying to accept its extra-historicity (on the other side of transformation), looks for it primarily in this unity all the way to the obsessive motive of the organic. The absence of the organic is a guarantee of disaster" (247). "Metaphysical fascism" of both the Old and New Right is the product of modernity. As such, it has always offered itself to provide justifications for conservative attacks on that very modernity.

Evola's fundamental ideological operation consists in projecting his political imperatives back into a distant and unverifiable past and then generalizing and expanding them to the level of universal history. This circular argument presents itself as an unimpeachable logic. Evola's "metaphysical history" is propelled by a "methodology" in which "racial memory," "recollection," "tradition," and "analogy" take the place of material evidence, causality, and chronology. This is outlandish historiography, to say the least. For example, Evola places the starting point of the waning of the West somewhere "between $8^{\text {th }}$ and $6^{\text {th }}$ century BCE" (Evola 10), way before Oswald Spengler and other theoreticians of western decadence. According to him, this decline was uneven, and it was punctuated by instances of partial resurfacing of the principle of "authentic empire." They were few and far between: early ancient Greece, especially Sparta, the ancient Roman Empire, and in the medieval Holy Roman Empire. Contrary to established historical narratives, Evola holds that the Renaissance initiated a period of steady degeneration, which reached its nadir with the onset of modernism. This relentless focus on the distant past doesn't mean that 
Evola and his acolytes don't pay any attention to the future. Like the spatial layout of this classical stately ideal, its temporal organization is defined by boundaries and limits. In the same way in which they are obsessed with walls and enclosures in space, they are invested in the notion of beginnings and ends in time. Here again, the province reveals the deeply rooted properties of the empire. It is not less defined by its spatial insularity than with its interminable anticipation of the end. Konstantinović emphasizes that the "end is the largest, perhaps a crystal-clear parochialism of the spirit"; further, "there is no belief in the end through which the parochial spirit does not speak, itself a work of that belief brought to a religious fetishization of the end in everything: in reality, in meaning, in history," so that "there is no final renunciation of the final meaning." Surely, there is "no end to the end" (Konstantinović 238). It turns out that this obsession with the end easily turns into a powerful political instrument.

\section{The joys of dark times}

In 1979, Kalajić published his collected magazine articles under the title Doomsday (Smak sveta), in which the initiates of "traditionalism" could easily recognize one of its central doctrines, that of cyclical history, or the eternal return. Here, he uses a number of western myths and eastern traditions to elaborate on the idea of "four ages," which are often characterized by the symbolism of four metals, as in Hesiod: gold, silver, bronze, and iron (Kalajić, Smak 229). The most distant, the purest, and at the same time the most ideal, is the age of gold; the most recent is the lowest, polluted, and unstable: the age of iron, or in the Biblical story of the prophet Daniel, of clay (230). The ages of clay and iron are at a furthest possible distance from the golden age; while the latter is the time of "boreal" and "Aryan" races, the former is the age of modernity. According to this doctrine, the truth of history is evident and unambiguous: it is enough to look at the world in which we live to see that the end is nigh. This is, of course, another major property of parochialism. Konstantinović saw this self-justifying claim at work in palanka: "The destruction of the Earth is true, that is, truth itself at work, the truth of the Earth that attains its reality and is filled and affirmed by it, thus reaching its end" (109). He described this pattern of thinking as an "apocalyptical cosmism," and this turns out to be one of very few of his claims about right-wing totalitarianism where he stands corrected by Evola \& Co. Namely, the unique intervention of 
metaphysical fascism in millenarian thinking is to divorce the notion of the catastrophe from the idea of the apocalypse: while the latter is tied to the idea of total destruction of the world as we know it, the former designates a cataclysm followed by renewal.

In an attempt to give more specificity to the idea of four ages, Evola borrows from Hindu mythology the doctrine that divides history into cycles named satya-yuga, treat-yuga, dvapara-yuga, and kali-yuga. Each of them corresponds to one of the ages, from golden to dark, kaliyuga being the last one. In an article from the 1970s, shrewdly titled after this last period to ambiguously point to the current condition and a possible future of the country nicknamed "Yuga," Kalajić diligently explicates the difference between the Hinduist idea of "doomsday" and Christian apocalypse: unlike the latter, the former does not represent the end of history, but just the conclusion of one and the beginning of another cycle, or the return of the golden age (Kalajić, Smak 178). It doesn't take too much effort to show that this is really the "kali" age, for which late $20^{\text {th }}$ century offers ample evidence: from consumerism to social upheavals, to gender equality, to queer rights, to the general availability of contraception; even body art is a sign of the times. With its pathos, feigned concern for the world, and open disgust with modernity, Kalajićs article is an epitome of the parochial worldview. Konstantinović recognizes nihilism as a hallmark of this outlook and even parses out its several different variants, such as realistic nihilism, erotic nihilism, and aristocratic nihilism. And this last kind concerns his seminal insight about the province: there is no more resounding affirmation of parochialism than its rejection, which most forcefully comes in the form of "parochial-anti-parochial aristocratism" (Konstantinović, Philosophy 176). This is an "enlightened" nihilism: "Unquestioned in the world of absolute truth, denied in it as in a 'higher' world it will never reach (guided by its 'realistic' prudence), it is simultaneously 'free' from any responsibility; if the mechanics of truth is free from it and function outside its will, it is free from responsibility: not one of its acts is important. In acting, it can be free, one way or another. Its ruthlessness and its egotism are inconceivable without this 'disillusion,' i.e., conviction in its own unquestionedness in matters of the world" (166). This freedom without responsibility is the source of the New Right's ethical recklessness.

Kalajić concludes The Stronghold, which, it is worth remembering, he "rediscovered" in the "catastrophic" month of November 1989, with three "limit figures." This first of these three princes of the endless end is the dandy, the second is the nihilist, and the third is the 
samurai. According to Kalajić, for these "aristocrats" of the twilight of modernity, any catastrophic event has an "undoubtedly positive meaning because it accelerates the process of decomposition and catastrophe, thus clearing the field for the future rise of the new order" (Kalajić, Uporiste 137). Epigones often go further than their masters, and Kalajić doesn't hesitate to state plainly what Evola only insinuated when he stated, already in his early Dadaist manifestos: "we know what we are doing because we own destruction and destruction doesn't own us" (qtd. in Schnapp 39). Namely, he claims that the nihilist refuses to capitulate to the catastrophe, but strives to "take hold of" it, "to enlarge it, [...], and in doing so accelerate the inevitable outcome of the final explosion of the human" (Kalajić, Uporišste 231). Reaching towards overcoming humanity, this integral man "is not possessed by evil, but possesses evil, which in his hands turns into an instrument of general and personal catharsis. Only a man who knows evil by provoking it can tame evil. Here, the testing of evil acquires the meaning of the trial of man's worth. Instigation of evil, that is to say, magnification of the elemental powers of catastrophe leads, dialectically, towards good" (232). Here, "dialectics" is a mental technique and not a philosophical procedure. It serves to justify political monstrosity, and not to grasp historical processes.

Since the collapse of the Soviet Union, there has been an ongoing debate among political scientists and historians if 1989 should be seen as a revolution or a counter-revolution. Seen from the perspective of the "philosophy" of the New Right, neither one of these categories is appropriate. It led to a relapse and amplification of some of the darkest ideas of the Old Right. In Yugoslavia, the doomsayers got what they called for, and then some. That fateful year, Konstantinović clearly saw this unabashed evil becoming part of the daily political discourse. He said as much in his address during a round table organized in Sarajevo to mark the $20^{\text {th }}$ anniversary of the publication of The Philosophy of Parochialism. Recognizing that "there is something tragic" in nationalists as the main "sufferers" of the parochial spirit, he wondered if, "at the bottom of their evil there was a hidden tear, as a tear of self-betrayed humanitarianism, or humanitarianism which in the midst of this contradictory, that is to say, the extremely conflicted world, tries to accomplish, hic et nunc, an ideal-'nonconflictual' world" (Konstantinović, "Iskušenje" 277). Thirty years later, and fifty years after the publication of his book, it turns out that Konstantinović was too gentle and forgiving towards these "Ghibellin militias," to use Kalajić's term of endearment for fascist thugs (Kalajić, "Uvod"). 
The political upheaval of 1968 prepared 1989, but not in a way anyone anticipated. The New Right adopted and disseminated the ideas of traditionalism and "metaphysical fascism" that invaded the post-Cold War ideological landscape. As philosophically unrigorous, as manipulative, and as opportunistic as it has been from its inception, the New Right infiltrated public discourse across the former East and the former West much more effectively than the New Left. If it appeared better suited for the age of digital technologies and of social media, that is because it prepared for it by adopting the strategies of the left while severely attacking its values. Typical for this tendency is de Benoist's keynote address at GRECE's $16^{\text {th }}$ congress held under the title "For a Gramscism of the Right," in which he called the New Right to take to heart the idea that culture is the principal road towards establishing political hegemony. He called for a "change of fundamental principles," for a departure from "dominant problematics, in which liberalism and socialism appear as the opposite poles of the same egalitarian matrix. We need to continue to produce a coherent theory, to propose a different worldview, a different civilizational project, a different concept of man and life" (Benoist 20). Different, but old, based on the ideas of the likes of Evola, which entered Eastern Europe and transformed its ideological landscape in a way that became perceptible only in recent years. By now, ideologues of the right, such as Steve Bannon in the US and Alexander Dugin in Russia, count him as their ideological precursors. His books are accessible more than ever thanks to the publishers such as Arktos Media, which started in Sweden but since then moved to Hungary, a move resplendent with political symbolism. With its expansion, the New Right is becoming less picky about its preferences: gone is its distance from electoral politics, and its critique of American neo-conservatism, while its appetite for the catastrophe remains unabated. Now firmly entrenched in global political and business elites, the ideas of the New Right are making international institutions dangerously ineffective to address the challenges of the $21^{\text {st }}$ century, such as climate change and extreme economic imbalances. This time, the "catastrophe," which the metaphysical fascists so eagerly anticipated, could be of apocalyptic proportions. There could be nothing left to be made great again. 


\section{WORKS CITED}

Barilli, Renato. Comportamento: Biennale di Venezia 1972, Padiglione Italia. Milan: Silvana Editoriale, 2017.

Benoist, Alain de. "Les causes culturelles du changement politique." Pour un "gramscisme de droite": actes du XVIème Colloque national du G.R.E.C.E. Paris: Labyrinthe, 1982. 9-22.

Chakrabarty, Dipesh. Provincializing Europe: Postcolonial Thought and Historical Difference. Princeton: Princeton University Press, 2007.

Evola, Julius. Revolt Against the Modern World. Trans. Guido Stucco Rochester. Vermont: Inner Traditions International, 1995.

Furlong, Paul. Social and Political Thought of Julius Evola. London: Routledge, 2011.

Kalajić, Dragoš. Krševina. Belgrade: Nezavisno autorsko izdanje, 1968.

Kalajić, Dragoš. Uporište. Belgrade: Delo, 1971.

Kalajić, Dragoš. Smak sveta. Zagreb: Nakladni zavod Matice hrvatske, 1979.

Kalajić, Dragoš. “Maj 1968+20=0.” Duga (1988): 20-22.

Kalajić, Dragoš. "Potemkinova imperija." Duga 410 (1989): 40-44.

Kalajić, Dragoš. “Uvod u delo Juliusa Evole.” Metafizika seksa. By Julius Evola. Čačak; Gradac: n.p., 1990.

Konstantinović, Radomir. The Philosophy of Parochialism. Ann Arbor: University of Michigan Press, 2021. Forthcoming.

Konstantinović, Radomir. "Iskušenje duha-anti-duha palanke." Sveske 7.26-27 (1989): 276-278.

Mammone, Andrea. "The Transnational Reaction to 1968: Neo-fascist Fronts and Political Cultures in France and Italy." Contemporary European History 17.2 (2008): 213-236.

Schnapp, Jeffrey. "Bad Dada (Evola)." The Dada Seminars. Eds. Leah Dickerman and Matthew S. Witkowsky. Washington, DC: The National Gallery of Art, 2005. $31-55$.

\section{Lastništvo zla: 1968, 1989 in integracija nove desnice}

Ključne besede: umetnost in politika / SFRJ / 1968-1989 / nova desnica / Evola, Julius / Kalajić, Dragoš / Konstantinović, Radomir: Filozofija palanke / metafizični fašizem / provinca / imperij

1968 je bilo prelomno leto ne samo za novo levico, ampak še bolj za vzpon nove desnice. Izkazalo se je, da če je leto 1968 "pripravilo« leto 1989 kot naslednjo prelomnico v evropski in svetovni zgodovini, se je verjetno to zgodilo bolj s pomočjo idej nove desnice, ki so sčasoma zagotovile ideološko utemeljitev za neliberalne demokracije v srednji in vzhodni Evropi. Jugoslavija je pomembno 
mesto v tej zgodovini ne le zaradi zgodnje izpostavljenosti idejam nove desnice prek dela slikarja in publicista Dragoša Kalajića, temveč tudi zato, ker je Radomir Konstantinović v svoji temeljni knjigi Filozofija palanke (1969) predvidel vzpon nove desnice in ponudil prodorno kritiko njenih temeljnih izhodišč.

1.01 Izvirni znanstveni članek / Original scientific article UDK 930.85(497.1)"1968/1989"

$323.233(497.1)^{\prime \prime} 1968 / 1989 "$

DOI: https://doi.org/10.3986/pkn.v43.i3.03 